\title{
PAOLO DI PAOLO, Amare come un padre: "Il Padre Goriot" di Honoré de Balzac
}

\section{Marco Stupazzoni}

\section{OpenEdition}

\section{Journals}

\section{Edizione digitale}

URL: http://journals.openedition.org/studifrancesi/16509

DOI: 10.4000/studifrancesi. 16509

ISSN: 2421-5856

\section{Editore}

Rosenberg \& Sellier

\section{Edizione cartacea}

Data di pubblicazione: 1 juillet 2019

Paginazione: 174

ISSN: 0039-2944

\section{Notizia bibliografica digitale}

Marco Stupazzoni, «PAolo di PAolo, Amare come un padre: "Il Padre Goriot" di Honoré de Balzac», Studi Francesi [Online], 187 (LXIII | I) | 2019, online dal 01 juillet 2019, consultato il 24 janvier 2021. URL: http://journals.openedition.org/studifrancesi/16509; DOI: https://doi.org/10.4000/studifrancesi. 16509

Questo documento è stato generato automaticamente il 24 janvier 2021.

\section{(c) (i) (9)}

Studi Francesi è distribuita con Licenza Creative Commons Attribuzione - Non commerciale - Non opere derivate 4.0 Internazionale. 


\title{
PAOLO DI PAOLO, Amare come un padre: "Il Padre Goriot" di Honoré de Balzac
}

\author{
Marco Stupazzoni
}

\section{NOTIZIA}

PAOLO DI PAOLO, Amare come un padre: "Il Padre Goriot" di Honoré de Balzac, in Vite che non sono le tue. Il bello dei romanzi in 27 storie, Bari-Roma, Editori Laterza, 2017, «Robinson / letture», pp. 111-116.

1 Attraverso la figura del Père Goriot e grazie al racconto del suo tragico destino, Balzac mostra di possedere una «sovrumana confidenza con l'umano» (p.112), con una umanità impressionante per varietà tipologica, per ambiguità psicologica, di carattere e di comportamento. Nel torbido oceano parigino, dove i vizi e le virtù faticano molto spesso a distinguersi, lo scrittore fissa e lascia agire i propri personaggi: egli «li infilza come insetti, [...] li osserva non da giudice, ma da entomologo, meravigliato e disgustato allo stesso tempo» (p.114). Nella figura di Goriot, Balzac ha descritto e raccontato un padre che concentra in sé tutti i padri: nel momento del delirio che precede l'agonia, Goriot non rimane che l'ombra di se stesso, il ricordo di ciò che era. Balzac, però, «non lo lascia svanire nella pagina: resta come un monumento all'imperfezione umana, baciato da un po' di luce in fondo a un corridoio scuro» (p. 115). 